\title{
The Determinants of Level of Society Welfare Within Fiscal Decentralization Framework in Regional Autonomy Era
}

\begin{tabular}{|c|}
\hline Nuwun Priyono $^{\mathbf{1}}$, Siti Arifah \\
, Eva Wulandari ${ }^{1}$, Panji Kusuma Prasetyanto \\
${ }^{1}$ Department of Accounting, Universitas Tidar \\
${ }^{2}$ Department of Economics, Universitas Tidar \\
Corresponding Author: panjikusuma@untidar.ac.id \\
\hline
\end{tabular}

Received: March 2020 | Revised: June 2020 | Accepted: July 2020

\begin{abstract}
The purpose of this study is to prove to what extent the influence that fiscal decentralization, local financial performance, local government expenditure, Locally Generated Recurring Revenues or Pendapatan Asli Daerah (PAD), Profit-Sharing Fund or Dana Bagi Hasil (DBH), General Allocation Fund or Dana Alokasi Umum (DAU), and Special Allocation Fund or Dana Alokasi Khusus (DAK) have on the level of society welfare. The objects of this research are Regencies and Municipalities in Java Island. The data used in this study are the secondary. The data on balance sheet and realization report of the regional revenues and expenditure budget (APBD) are from the Ministry of Finance of the Republic of Indonesia. The data on the level of society welfare that is proxyed by the value of HDI is obtained from Bappenas and BPS of Central Java. This research uses time series data from 20122014 periods. The research method used is the research of causality with linear regression model. The result of the significance test shows that only one DAK variable can partially affect the HDI variable. Meanwhile those variables other than DAK partially or individually do not influence the HDI variable. The result of regression analysis shows that simultaneously such variables as Fiscal Decentralization, Regional Finance Performance, Local Government Expenditure, PAD, DAU, DAK and DBH have an influence on HDI in Regencies / Municipalities in Java Island.
\end{abstract}

Keywords: society, welfare, fiscal, decentralization

JEL classification: $04, \mathrm{O} 15$

How to Cite: Priyono, N., Arifah, S., Wulandari, E., \& Prasetyanto, P. K. (2020). The Determinants of Level of Society Welfare Within Fiscal Decentralization Framework In Regional Autonomy Era. Jurnal Ekonomi Pembangunan: Kajian Masalah Ekonomi dan Pembangunan, 20(2). 141-152. doi:https://doi. org/10.23917/jep.v21i2.10545

DOI: https://doi.org/10.23917/jep.v20i2.10545

\section{Introduction}

In Indonesia, since the application of regional autonomy, a problem about fiscal decentralization enough interesting to discuss. The reason is there has been a change in current fiscal decentralization scheme which provides equalization funds so big from the central government to local government, plus a few expansion of sources of income new for local governments(Rustan, 2013). The fiscal decentralization policy is a part of regional autonomy policy in the field of finance. This regional autonomy policy was initiated as a result of postSoeharto era known as the reform era. During this reform era changes occured in many life aspects including: social, economic, cultural, ideologic and politic aspects and even defense and security. Thanks to the demand from the society for income equality and minimization of inter-region gap, the regional autonomy has been one policy which is deemed capable of dealing with these problems. 
Jurnal Ekonomi Pembangunan: Kajian Masalah Ekonomi dan Pembangunan, 21 (2), 2020, 60-70

To find out how far regional financial capability presented in the necessary financial statements financial statement analysis is carried out with certain techniquesv(Wahyudi, Muhamad and Wulandari, 2017). Budget expenditure used in acquire non-current assets and other assets and impact the local government so it will provide benefits over one period called with Capital Expenditures. This capital expenditure is related tightly planned financial use within the long term, as for asset maintenance keep it. To implement financing of government administration and provide services to the community. regional governments can levy fees to the community related to local taxes or levies and welcome to manage the Source Nature's power independently. Type of Fund source at among the local governments are as following: PAD, Funds Balance of DAU and DAK and Regional Loans, Deconcentration and Co-Administration(Suryana, 2018).

In line with the objectives of fiscal decentralization mentioned, government financial transfers to central government implemented through some instruments through the shopping side regions on central government finance and revenue on government finances area. First is through instruments which conceptually is called fiscal balancing instrument. In practice at Indonesia is implemented through DBH both tax and non tax. Second through instruments that are based the terms and technical specifications can be said to be less conditioned-type instrument transfer. Instrument implementation this type is implemented through the DAU. These funds are allocated based on fiscal capacity of each region so hopefully it can compensate disparity in the ability of regions within finance development. Third, there is also the instruments of fiscal decentralization can be classified as conditionedtype transfer instrument, namely the DAK. DAK is allocated to the regions and certain sectors based on priority and the direction of national development. That No less important is the instrument PAD determine the fiscal capacity of a region to finance development in the area each(Doriza, Purwanto, \& Maulida, 2013).

This regional autonomy aims mainly at authorizing regions in managing themselves more extensively, particularly the authority in regional fiscal management. Regions have extensive authority in their financial management. Regional governments can explore the financial potentials existing in their areas to allow themselves to improve their people's welfare. With the package of regional autonomy laws, namely: Law No. 22 year 1999 and Law No. 25 Year 1999 which have been amended with Law No.32 Year 2004 and Law No. 34 Year 2004, regional autonomy has officially been implemented by every region. Thus, these regions will be able to reduce its financial resources dependence on the central government. Regions can find their own sources of local revenues. When a gap remains, these regions will still receive balancing fund from the central government. Under such circumstance above, regions have the potentials to improve their people's welfare through various regional development activities. Earlier, the only source of regional revenues prior to the reform era is the central government through its balancing fund. Thanks to regional autonomy through fiscal decentralization policy, regions can now manage their sources of regional revenues more extensively. These revenue sources include: Locally Generated Recurring Revenues or Pendapatan Asli Daerah (PAD), Profit-Sharing Fund or Dana Bagi Hasil (DBH), General Allocation Fund or Dana Alokasi Umum (DAU), Special Allocation Fund or Dana Alokasi Khusus (DAK) and many other sources of financing.

According to Barzelay (1991), giving regions some autonomy through fiscal decentralization has three main missions, namely:

a. To create regional resource management efficiency and effectiveness

b. To improve the quality of public services and the people's welfare.

c. To empower and create some space for the society to participate in the development process. 
Fiscal decentralization is required for economic efficiency improvement, cost efficiency, accountability improvement and fund mobilization improvement. Fiscal decentralization cannot be abruptly adopted, rather it has to be adjusted to the historical and cultural backgrounds, institutional, politic and economic dan ekonomi conditions inherent to that country (Sasana, 2009).

Meanwhile, Cassette, Aurelie \& Paty (2010) argue that decentralization is political, fiscal dan administrative shifts of power to local governments, arising out as a trend of highly important policy development. Greer (2010) defines decentralization as an extensive authority focusing on the central government's policy structure and the financial relationship between governments.

Fiscal decentralization can be measured using the regional financial independence ratio as indicated by the amount of Locally Generated Recurring Revenue (PAD) as compared to regional revenues from other sources, such as loans from the central government or other lendings (Halim, 2008). Meanwhile, Mahmudi (2011) suggests that to measure fiscal decentralization one can use decentralization degree as calculated based on the comparison between the amount of PAD to the total regional revenues. This ration indicates the degree of contribution of PAD to the total regional revenues. The higher the PAD contribution, the higher the regional government's capability in implementing decentralization. Performance is a depiction of accomplishment of an activity/ program/policy implementation in achieving an organizatio's ntargets, goals, missions, and vision (Bastian, 2006). Generally, performance is the achievement obtained by an organization within certain period of time. In measuring an organization's success/failure, it should not be done only to the input of a program, rather it should also be applied to the benefit outcome from such program. The financial performance of regional governments is a region's ability to explore and manage their sources of locally- generated revenues in fulfilling their own needs in order to support the administration of governmental system, services to the society and regional development (Nuritomo \& Rossieta, 2014).

Fiscal decentralization is expected to deal with the gap in terms of incoming revenues, which when managed properly will improve the people's welfare. Thereby, the regional government in implementing this fiscal decentralization within the regional autonomy framework should seriously set their goals on improving people's welfare, through various regional development programs. The debate on decentralization policy revolves around some issues. In relation to macroeconomic management, according to (Simanjuntak, 2010), the prominent key issues are the influence of decentralization on economic growth, equality, inflation, and public services. Some economists believe that fiscal decentralization drives growth, promotes equality, and improves the quality of public services and people's welfare. Based on teh background above, this research formulates its problems to study and prove how such factors as: fiscal decentralization, regional financial performance, regional government expenditure, Locally Generated Recurring Revenue (PAD), General Allocation Fund (DAU), Special Allocation Fund (DAK), and Profit-Sharing Fund (DBH) can have some influences on the improvement of people's welfare in this regional autonomy era in Regencies/Municipalities in Java Island.

The enactment of regional autonomy gives localgovernment theopportunity tofurther develop regional potential. To develop the potential of the area, the regional government needs to increase the capital expenditure budget. The sources of funds used to finance the capital expenditure consist of PAD, DAU, DAK and DBH (Wandira, 2013). Locally Generated Recurring Revenue (PAD) is all revenues received by regions from their efforts of exploring the financial potentials existing in their areas. In Law No 33. Year 2004 concerning Financial Balancing between Central and Regional (Governments) it is stated that 
Locally Generated Recurring Revenue (PAD) is classified as follows:PAD sources include: a. Regional Tax; b. Regional Retribution; c. proceeds of Region's severable property management; and d. other legitimate PADs. The other legitimate PADs include: a. Proceeds of sales of Region's non-severable properties; b. demand deposit interest; c. interest receipt; $d$. the profit from the difference of rupiah exchange rate against foreign currency; e. benefit, withdrawal, or other forms as a result of sales and/or procurement of goods and/ or services by the Region.

According to (Kuncoro, 2004) DAU is a block grant given to all regencies and municipalities to close the gap between fiscal capacities and needs. Under Law Number 33 Year 2004 concerning Financial Balancing between Central and Regional Governments Article 27, DAU for a region is allocated based on the basic allocation fiscal gap. According to Bratakusumah \& Solihin, 2004 (in (Adiputra, I.M.P, Dwiyantari , N.K.D \& Darmada, 2015)) General Allocation Fund is alloted for equality purpose by considering the region's potential, width, geographical state, number of population, and level of income of people in that region in order to minimize the income gap between regions. Special Allocation Fund (DAK) is alloted to certain regions to fund special activities constituting the region's affairs which have been established in APBN. Law No. 33 Year 2004 concering Financial Balancing between Central and Regional Governments Article 40 explains that the government sets three criteria in determining DAK, i.e. general criteria, special criteria and technical criteria. The general criteria are determined by considering the region's financial capability in APBD, criteria for procuring investment goods or certain facilities in the effort of providing services to the public the advantages of which can be enjoyed either directly or indirectly by the society. Under Law Number 33 Year 2004 article 11, it is stated that ProfitSharing Fund (DBH) is the region's fund portion including tax and natural resources. The tax in this case consists of property tax, income tax articles 25 and 29, domestic person taxpayer and income tax article 21 , and duty for acquiring rights of land and building. However, from January 1, 2014, the property tax is withdrawn by regions. Natural resources consist of forestries, general mining, fisheries, oil mining, natural gas mining, and geothermal mining. Human development is one of important things in people's life. Human development means the positive growth and changes in welfare levels. This has to occur in all life aspects, be it economic, social, political, cultural, and environmental. Therefore, the main focus of human development is on human and their welfare. The human development concept does sound different as compared to the classic development concept which pays its attention mainly to economic growth. This human development gives emphasis on the expansion of people's choices to live full of freedom and dignity. In addition, human development also talks about individual and community capability extension to expand their choice ranges in the effort of fulfilling their aspirations (BPS, 2015).

This research aims at: 1) Proving the extent of influence that fiscal decentralization has on the level of society welfare in Regencies/Municipalities in Java Island, 2) Proving the extent of influence that regional financial performance has on the level of society welfare in Regencies/Municipalities in Java Island, 3) Proving the extent of influence that regional government expenditure has on the level of society welfare in Regencies/ Municipalities in Java Island, 4) Proving the extent of influence that has PAD on the level of society welfare in Regencies/Municipalities in Java Island, 5) Proving the extent of influence that General Allocation Fund (DAU) has on the level of society welfare in Regencies/Municipalities in Java Island, 6) Proving the extent of influence that Special Allocation Fund (DAK) has on the level of society welfare in Regencies/Municipalities in Java Island, 7) Proving the extent of influence that Profit-Sharing Fund (DBH) has on the level of society welfare in Regencies/ Municipalities in Java Island. 


\section{Research Method}

Ministerial Regulation of Home Affairs Number 13 Year 2006 concerning Guidelines for Regional Financial Management states that performance is the outcome/output of an activity or program which will be achieved in relation to the use of budget at a well-measured quantity and quality. Performance is a depiction of accomplishment level of implementation of an organization's program in realizing the organization's goals, the pengeluaran hasil kerja organization's proceed expenditure, customer decision, and its contribution to the people's economic development (Suprasto, 2003). Syamsi (1986) in (Susantih, H \& Saftiana, 2009) suggests that a Regional Government's financial performance is the ability of a region to explore and manage their financial sources for locallygenerated revenues in order to meet their needs, hence being financially independent from the Central government. Furthermore, it will give the regions more spaces to use the fund for their people's interest within the limits allowed by regulations of law. (Susantih, H \& Saftiana, 2009) state that the use of financial ratio as a tool for analyzing financial performance has been widely applied in commerial corporate institutions. Meanwhile, its application in public institutions, particularly regional governments, is highly limited, hence theoretically no unanimous agreement has been reached regarding its name and the ways for measuring it. In the efffort of realizing a transparent, honest, democratic, effective, efficient, and accountable regional financial management, the financial ratio ratio is then applied to regional revenues and expenditure. (Mardiasmo, 2002). Regional financial efficiency ratio can serve as one of many ways to measure regional financial performance. According to (Halim, 2007), efficiency ratio is the ratio which illustrate the comparison between output and input or the expenditure realization and regional revenues realization. The lesser this ratio, the more efficient it is, and vice versa. The measurement of regional government performance can be done by assessing the efficiency of services provided to the society (Mahmudi, 2002). The calculation of efficiency ratio is as follows:

\section{Efficiency Ratio:}

(Expenditure Ratio/ Revenue Ratio) x 100\%

There are some government expenditures: namely routine and development expenditures (two budgetings). The routine expenditure is the one for the purpose of operating governmental routine activities. This routine expenditure include employee spending, goods spending, interest payment, subsidy, and other spendings. Meanwhile, development expenditure is defined as the one which produces asset's added value, both physical and non-physical, which is performed within certain period. Development expenditure is the one related to projects which involve capital expenditure and supporting expenditure (Rachmat, 2010). Article 36 of Ministerial Regulation of Home Affairs No. $13 / 2006$ states that expenditure by its groups consist of direct and indirect expenditures. Indirect expenditure is the one budgeted with not direct relation to the implementation of programs and activities. Meanwhile, direct expenditure is the one budgedt with direct relation to the implementation of programs and activities. Direct expenditure is classified based on the expenditure type comprising of employee spending, goods and services spending, and capital expenditure.

Meanwhile, according to (BPS, 2013) the concept of Human Development Index of international scale determines the performance rank of human development at 0.0-100.0 scale with the following categories:

High $\quad:$ HDI $\geq 80.0$

Upper Medium : $66.0 \leq \mathrm{HDI} \leq 80.0$

Lower Mediu : $50.0 \leq \mathrm{HDI} \leq 66$

Low $\quad:$ HDI $\leq 50.0$ 
The current research refers to those previous studies in the same realm. The results of (Adiputra, I.M.P, Dwiyantari, N.K.D \& Darmada, 2015) research prove that Locally Generated Recurring Revenue (PAD) has direct influence on human development quality in Regencies/ Municipalities in Bali. Locally Generated Recurring Revenue (PAD) has indirect influence on human development quality through regional expenditure allocation of regencies/municipalities in Bali. Meanwhile, SiLPA through capital expenditure allocation can be used to improve the human development quality in regencies/ municipalities in Bali. As to DAU, DAK and $\mathrm{DBH}$, they have not been able to influence human development quality since they are not fully allocated as capital expenditures. Another research is conducted by Anggraini (2015) which studies the influence of regional government's financial ratio on human development index in Provincial Governments throughout Indonesia, proving that Decentralization Degree Ratio and Regional Financial Independence Ratio have some influence on HDI. This research will test to what extent fiscal decentralization, regional financial efficiency ratio and regional government expenditure directly influence the level of society welfare, and indirectly influence the level of society welfare through economic growth in Regency/ Municipality Governments in Central Java.

This research uses secondary data with its data time series being 2012-2014 period. Meanwhile, the obtained data take the form of balance sheet report and the realized revenue of the regional revenues and expenditure budget (APBD) from the Financial Balancing Directorate General of the Ministry of Finance of the Republic of Indonesia. From these data, information about fiscal decentralization degree ratio, financial efficiency ratio, regional government expenditure, PAD, DAU, DAK, and Profit-Sharing Fund will be found. Furthermore, the data on Human Development Index (HDI) come from the Central Statistics Agency (BPS). These data from Ministry of Finance of the Republic of Indonesia and BPS are obtained via internet. The samples are taken using purposive sampling. i.e. a technique of determining samples with certain considerations (Sugiyono, 2009). Using this sampling technique, the samples of 99 regencies/municipalities in Java Island are obtained, which include: East Java, Central Java, D.I Yogyakarta, West Java and Banten Provinces. From each of these provinces 8 regencies/municipalities are taken as sample, 4 of which have upper medium HDI and 4 others have lower medium HDI. From the Special Capital District of Jakarta Province no sample is taken due to the limited research data.

The indicators or variables observed in this research are dependent and independent variables. The dependent variable in this research is level of society welfare which will be measured by looking at the Human Development Index (IPM) scores. Meanwhile, the independent variables in this research are: fiscal decentralization which will be measured by counting the decentralization degree ratio which is obtained from comparing PADs, divided by the total revenue in percent unit. Furthermore, the regional government's financial performance will be measured by counting the regional financial efficiency ratio by comparing the total realized expenditure divided by the total realized revenue, measured in percentage. Regional government expenditure is measured by counting the total spending both the direct and indirect ones in rupiah unit. PAD, DAU and DAK will be measured in rupiah unit. Profit-Sharing Fund (DBH) which include tax profit sharing and natural resources profit sharing, is measured in rupiah unit.

The hypothesis testing is done using multiple regression analysis model, aiming at predicting the extent of influence that the independent variables have on the dependent variable. The technique used in this regression analysis is ordinary least squares (Gujarati, 2003). The regression equation is:

$$
\begin{aligned}
& \mathrm{HDI}=\alpha+\beta_{1} \mathrm{FDec}+\beta_{2} \mathrm{RFP}+\beta_{3} \mathrm{RGE}+ \\
& \beta_{4} \mathrm{LGR}+\beta_{5} \mathrm{GAF}+\beta_{6} \mathrm{SAF}+\beta_{7} \mathrm{GRS}+\mathrm{e}
\end{aligned}
$$


where: HDI $=$ Level of Society Welfare, $\alpha=$ Constant, $B=$ Slope or regression coefficient or intersept, FDec = Fiscal Decentralization, RFP = Regional Financial Performance, RGE $=$ Regional Government Expenditure, LGR = $\mathrm{PAD}, \mathrm{GAF}=\mathrm{DAU}, \mathrm{SAF}=\mathrm{DAK}, \mathrm{GRS}=\mathrm{DBH}, e$ $=$ error. The multiple linear regression equation in this research model will be tested using data processing software SPSS version 20. Prior to this testing to the multiple linear regression, a classical assumption testing is done first, which consists of normality test, multicollinearity test, autocorrelation test and heteroskedasticity test. The classical assumption test performed above should show result of normality, free from multicolliniearity, free from autocorrelation and free from heteroskesdasticity (Ghozali, 2006)

\section{Results And Discussion}

3.1 Results

Upon the classical assumption test, the linear regression model does not find any issue in normality, multicolliniearity, and heteroskesdasticity. The only issue found is in positive autocorrelation. Based on the results of classical assumption testing, to the linear regression model further testings can be done, i.e. simultaneous and partial testings. The simultaneous testing is done using $\mathrm{F}$ test, and the partial testing is done using $t$ test.

These partial and simultaneous testings are done using data processing software SPSS version 20. The output of multiple linear regression using SPSS version 20 is shown in the tables 1:

Table 1. Outcome of Individual Significance Test (t Statistic Test)

\begin{tabular}{|c|c|c|c|c|c|c|c|c|}
\hline \multicolumn{9}{|c|}{ Coefficientsa } \\
\hline & \multirow[t]{2}{*}{ Model } & \multicolumn{2}{|c|}{$\begin{array}{c}\text { Unstandardized } \\
\text { Coefficients }\end{array}$} & \multirow{2}{*}{$\begin{array}{c}\begin{array}{c}\text { Standardized } \\
\text { Coefficients }\end{array} \\
\text { Beta } \\
\end{array}$} & \multirow[t]{2}{*}{$\mathbf{T}$} & \multirow[t]{2}{*}{ Sig. } & \multicolumn{2}{|c|}{$\begin{array}{l}\text { Collinearity } \\
\text { Statistics }\end{array}$} \\
\hline & & B & Std. Error & & & & Tolerance & VIF \\
\hline \multirow[t]{8}{*}{1} & (Constant) & 79.623 & 6.963 & & 11.435 & .000 & & \\
\hline & FDec & 9.448 & 8.476 & .158 & 1.115 & .268 & .201 & 4.971 \\
\hline & $\mathrm{RFP}$ & -10.209 & 6.936 & -.103 & -1.472 & .145 & .826 & 1.211 \\
\hline & RGE & $1.535 \mathrm{E}-006$ & .000 & .228 & 1.517 & .133 & .179 & 5.588 \\
\hline & LGR & $2.277 \mathrm{E}-006$ & .000 & .139 & .694 & .489 & .101 & 9.900 \\
\hline & GAF & $-1.356 \mathrm{E}-006$ & .000 & -.072 & -.573 & .568 & .257 & 3.886 \\
\hline & SAF & $-7.951 \mathrm{E}-005$ & .000 & -.529 & -4.753 & .000 & .326 & 3.064 \\
\hline & GRS & $5.775 \mathrm{E}-007$ & .000 & .007 & .084 & .933 & .518 & 1.932 \\
\hline
\end{tabular}

a. Dependent Variable: HDI

Table 2. Result of Simultaneous Significance Test (F Statistic Test)

\begin{tabular}{|c|c|c|c|c|c|c|}
\hline \multicolumn{7}{|c|}{ ANOVA $^{a}$} \\
\hline & Model & $\begin{array}{l}\text { Sum of } \\
\text { Squares }\end{array}$ & Df & $\begin{array}{l}\text { Mean } \\
\text { Square }\end{array}$ & $\mathbf{F}$ & Sig. \\
\hline \multirow[t]{3}{*}{1} & Regression & 2086.696 & 7 & 298.099 & 22.314 & $.000^{b}$ \\
\hline & Residual & 1215.711 & 91 & 13.359 & & \\
\hline & Total & 3302.407 & 98 & & & \\
\hline
\end{tabular}

a. Dependent Variable: HDI

b. Predictors: (Constant), GRS, RFP, SAF, RGE, FDec, GAF, LGR 
Avalaible online at http://journals.ums.ac.id, Permalink/DOI: 10.23917/jep.v21i2.10545

Jurnal Ekonomi Pembangunan: Kajian Masalah Ekonomi dan Pembangunan, 21 (2), 2020, 60-70

Table 3. Result of Determination Coefficient

\begin{tabular}{|c|c|c|c|c|c|}
\hline \multicolumn{6}{|c|}{ Model Summary $^{\mathbf{b}}$} \\
\hline Model & $\mathbf{R}$ & R Square & $\begin{array}{c}\text { Adjusted R } \\
\text { Square }\end{array}$ & $\begin{array}{c}\text { Std. Error of the } \\
\text { Estimate }\end{array}$ & Durbin-Watson \\
\hline 1 & $.795^{\mathrm{a}}$ & .632 & .604 & 3.6551 & 1.269 \\
\hline
\end{tabular}

Table 1 shows the result of $t$ significance test, where it is found that only variable X6: Special Allocation Fund (DAK) partially/individually can influence variable Y (HDI) which describe the level of society welfare. This is because its significance value is below $5 \%$ or 0.05 . Meanwhile, the other six independent variables show significance values far above 0.05 , hence partially it cannot influence the dependent variable.

The result of Anova test shows that the $\mathrm{F}$ statistic value is 22.314 with a probability of 0.000 . Since the probability value is far lesser than 0.05 or below $5 \%$, then the regression model can be used to predict the level of society welfare (HDI) or it can be said that the Fiscal Decentralization (FDec), Regional Financial Performance (RFP), Regional Government Expenditure (RGE), PAD (LGR), DAU (GAF), DAK (SAF) dan DBH (GRS) variables simultaneously have some influence on the Level of Society Welfare (HDI).

The determination coefficient $\left(R^{2}\right)$ in essence measures to what extent the model can explain the dependent variable variation. The determination coefficient value is between null and one. In table 3 below, it is shown that the value of adjusted $R^{2}$ is 0.604 or $60.4 \%$. It means the dependent variable HDI is influenced by Fiscal Decentralization (FDec), Regional Financial Performance (RFP), Regional Government Expenditure (RGE), PAD (LGR), DAU (GAF), DAK (SAF) dan DBH (GRS) variables at $60.4 \%$, and the remaining $39.6 \%$ is influenced by those variables other than these six independent variables. This value indicates that the ability of independent variables in explaining the dependent variable variation is fairly strong, since the value is close to 1 .

\subsection{Discussion}

Human Development Index (HDI) describes the people's life feasibility standards as seen from many aspects such as: education, health, economic level and so forth. This measurement reflects the level of society welfare. The human development concept has wider scope than the conventional economic development theory. The economic growth model puts more emphasis on increasing Gross National Product (GNP) than on improving life quality. Hence, there is a shift of welfare approach which views human as the recipient, rather than an agent of change in the development process (BPS, 2015). In its development, the level of society welfare which can also be reflected from the Human Development Index (HDI) can be influenced by many factors, such as: Fiscal Decentralization (FDec), Regional Financial Performance (RFP), Regional Government Expenditure (RGE), PAD (LGR), DAU (GAF), DAK (SAF) dan DBH (GRS). From the determination coefficient according to the result of statistic data processing, the adjusted $R^{2}$ value is 0.604 or $60.4 \%$. It proves that $60.4 \%$ of HDI factors can explain their influence variation on the dependent variable (HDI). The factors influencing HDI are the independent variables consisting of: Fiscal Decentralization (FDec), Regional Financial Performance (RFP), Regional Government Expenditure (RGE), PAD (LGR), DAU (GAF), DAK (SAF) dan DBH (GRS). In relation to the magnitude of influence these factors have on HDI which can be seen from its value of $60.4 \%$, this indicates that the level of society welfare is influenced by the value of fiscal decentralization degree. This value illustrates the regional government's financial ability/independence. It 
means the regional government's fiscal power can influence the level of society welfare. Furthermore, regional government's financial performance and Regional Government Expenditure can also explain their influence on the HDI/level of society welfare variable at $60.4 \%$. Other factors such as: PAD and balancing fund can also explain their influence on HDI variable. The regency/ municipality government's ability in exploring their potentials and gearing up $\mathrm{PAD}$ from various revenue sector can also influence the level of society welfare. The greater the PAD received the greater the chance to improve their people's welfare. This is because PAD fund can be used as a source of regional development fund. Meanwhile, an equally important factor is balancing fund, which include: DAU, DAK and Profit-Sharing Fund (DBH). This balancing fund is the fund transferred from the central government which is also used as one of development fund sources. Hence, this balancing fund can also influence the level of society welfare.

To see to what extent the influence that independent variables have on the dependent variable (HDI), one can see the significance value of both the $\mathrm{t}$ statistic test and the $\mathrm{F}$ statistic test. The partial test can be seen from $t$ statistic test and the simultaneous test can be seen from $\mathrm{F}$ statistic test. The result of partial testing shows a significance value below 0.05 only for variable SAF i.e.: DAK. It means that partially/individually only the Special Allocation Fund (DAK) variable can influence HDI variable. Law No 33 Year 2004 states that Special Allocation Fund (DAK) is the fund from APBN revenue alloted to certain regions to help them fund the special activities for which these regions are responsible and in accordance with the national priority. Judging from this definition, it is clear that DAK is a fund source specifically alloted to finance special programs/activities which cannot be fulfilled yet from many sources including DAU and DBH. Examples of these special programs are procurement of facilities and infrastructures in remote areas, construction of primary irrigation, construction of roads in remote areas with hard access to them and so on. This special use of fund will surely directly promotes the rapid improvement of people's welfare in those areas in which the developments are done. The DAK allocated to regions in Java Island which are in desperate need of development program priorities will accelerate/support the improvement of level of society welfare. Meanwhile, other variables cannot influence the level of society welfare just yet.

Furthermore, the result of simultaneous test using $\mathrm{F}$ significance value indicates a significance value of 0.000 or below 0.05 . This value shows that simultaneously the independent variables such as: Fiscal Decentralization, Regional Financial Performance, Regional Government Expenditure, PAD, DAU, DAK and DBH have some influence on the dependent variable (HDI) which reflects the level of society welfare. Partially, only DAK variable can influence HDI variable. Hoever, simultaneously the seven independent variables can influence HDI variable. This result confirms the research conducted by Adiputra, I.M.P, Dwiyantari, N.K.D \& Darmada (2015) which proves that Locally Generated Recurring Revenue (PAD) has direct influence on human development quality in Regencies/Municipalities in Bali. It also support the results of research conducted by Priyono, Poerba, \& Iswanaji, (2016) on the influence of Fiscal Decentralization and PDRB on the level of society welfare as proven by the fact that Fiscal Decentralization Degree (FDD) and PDRB variables collectively have some influence on the dependent variable, level of society welfare. Moreover, it confirms the research conducted by Saputra (2011) which shows that fiscal decentralization has positive influence on People's Welfare.

From this result of simultaneous test, it can be analyzed that the fiscal decentralization degree simultaneously with other variables influences the HDI variable. It proves that the regional financial independence level can influence level of welfare, provided that other variables also influence it. The more independent the region, in a sense that it is no longer dependent on the central government, the more likely it supports its people's welfare. Moreover, the regional financial 
performance variable illustrates how the regency/ municipality governments in Java Island can absorb budgets during a budget year. The higher the regional government's financial performance, the greater the absorption/realization of the budget would be. Of course, many government's programs can then be realized from various fields including education, health, economic and others, which indirectly can promote the people's welfare improvement.

The next variable which can influence the level of society welfare provided that there are other variables concurrently influence it is Regional Government Expenditure, either direct or indirect spendings. Furthermore, the PAD variable is also the same, it can simultaneously with other variables influence the level of society welfare. Finally, the balancing fund variable consisting of DAU, DAK and DBH can also collectively influence the level of society welfare (HDI) variable when the fiscal decentralization, regional government's financial performance, Regional Government Expenditure dan PAD variables concurrently play a role in influencing it. DAU is the fund transferred from the central to regional government in order to help reduce interregion gaps. If DAU can be allocated according to the fiscal needs existing in these regions and used to finance public service activities in many fields, it can then support the improvement of people's welfare. The same applies to DAK and ProfitSharing Fund (DBH). When these two sources can be allocated to regions, they can also support the improvement of people's welfare

\section{Conclusion}

Special Allocation Funds for the variable Human Development Index (HDI). While variables other than DAK do not depend on the HDI variable (level of community welfare). By variable simultaneous variables Fiscal Decentralization, Regional Financial Performance, Local Government Expenditure, PAD, DAU, DAK and DBH are allocated to HDI to Regency / City Governments in Provinces in Java Island. Furthermore, this research uses as its samples the Regencies /Municipalities in Provinces in Java Island. Therefore, for future research it is highly recommended to use a more wider sample, i.e. Regencies/Municipalities outside Java Island, to give a more comprehensive illustration on Human Development Index (HDI) which reflects the level of society welfare. There is a need to allocate a more significant Special Allocation Fund (DAK) so that DAK can finance the government's priority programs in special areas in many regencies/ municipalities in Java Island.

\section{References}

Adiputra, I.M.P, Dwiyantari ， N.K.D \& Darmada, D. K. (2015). Pengaruh PAD, Dana Perimbangan dan SiLPA Terhadap Kualitas Pembangunan Manusia Dengan Alokasi Belanja Modal Sebagai Variabel Intervening (Studi Pada Pemerintah Kabupaten/Kota di Bali). Prosiding SNA 18.

Anggraini, T. \& S. (2015). Pengaruh Rasio Keuangan Pemerintah Daerah Terhadap Indeks Pembangunan Manusia Pemerintah Propinsi di Indonesia. Prosiding SNA 18.

Barzelay, M. (1991). Managing Local Development Lesson from Spain. Policy Sciences, 271 290.

Bastian, I. (2006). Sistem Akuntansi Sektor Publik. Salemba Empat (Edisi 2). Jakarta.

BPS. (2013). Pembangunan Manusia Indonesia Tahun 2012 : Metode Baru.

BPS. (2015). Indeks Pembangunan Manusia Indonesia Tahun 2014: Metode Baru.

Cassette, Aurelie \& Paty, S. (2010). Fiscal decentralization and the size of government: a European country empirical analysis. Public Choice, 143, 173-189.

Doriza, S., Purwanto, D. A., \& Maulida, E. (2013). Fiscal Decentralization and Disparity of Access to Primary Education in Indonesia Desentralisasi Fiskal dan Disparitas Akses Pendidikan Dasar di 
Jurnal Ekonomi Pembangunan: Kajian Masalah Ekonomi dan Pembangunan, 21 (2), 2020, 60-70

Indonesia Pendahuluan. Jurnal Ekonomi Pembangunan: Kajian Masalah Ekonomi Dan Pembangunan, 14(2), 223-233.

Ghozali, I. (2006). Aplikasi Analisis Multivariate dengan Program SPSS. In E. IV (Ed.), Badan Penerbit UNDIP. Semarang.

Greer, S. L. (2010). How Does Decentralisation Affect the Welfare State? Territorial Politics and the Welfare State in the UK and US. Soc.Pol, 39,2, 181-201.

Gujarati, D. (2003). Basic Econometric. McGrawhill. New York.

Halim, A. (2007). Akuntansi Keuangan Daerah. Penerbit Salemba Empat. Jakarta.

Halim, A. (2008). Akuntansi Keuangan Daerah. Salemba Empat (Edisi Ketiga). Jakarta.

Kuncoro, H. (2004). Pengaruh Transfer Antar Pemerintah Pada Kinerja Fiskal Pemerintah Daerah Kota dan Kabupaten Di Indonesia. Economic Journal of Emerging Markets, 9(1), 47-63..

Mahmudi. (2002). Manajemen Kinerja Sektor Publik. UPP STIM YKPN. Yogyakarta.

Mahmudi. (2011). Akuntansi Sektor Publik. UII Press (Cetakan Pe). Yogyakarta.

Mardiasmo. (2002). Otonomi Daerah dan Manajemen Keuangan Daerah. Penerbit Andi. Yogyakarta.

Nuritomo \& Rossieta. (2014). Politik Dinasti, Akuntabilitas dan Kinerja Keuangan Pemerintah Daerah di Indonesia. Prosiding SNA 17.

Priyono, N., Poerba, M. A., \& Iswanaji, C. (2016). Analisis Pengaruh Desentralisasi Fiskal dan PDRB Terhadap Tingkat Kesejahteraan Masyarakat dan Tingkat Pengangguran Terbuka Pada Kabupaten/ Kota di Propinsi Jawa Tengah. Prosiding Seminar Nasional FE Untidar, 313-326.

Rachmat. (2010). Akuntansi Pemerintahan. Penerbit CV Pustaka Setia. Bandung.

Rustan, A. (2013). Relation With Regional
Autonomy. Jurnal Borneo Administrator, 9(3), 284-304.

Saputra, B. (2012). Pengaruh Desentralisasi Fiskal Terhadap Pertumbuhan Ekonomi dan Kesejahteraan Masyarakat. Jurnal Akuntansi dan Auditing Indonesia, 16(2), 185-199.

Sasana, H. (2009). Peran Desentralisasi Fiskal Terhadap Kinerja Ekonomi di Kabupaten/ Kota Provinsi Jawa Tengah. Jurnal Ekonomi Pembangunan, Vol. 10 No. 1, 103124.

Simanjuntak, R. A. (2010). Desentralisasi Fiskal dan Manajemen Makroekonomi: Urgensi Suatu Grand Design di Indonesia. Prisma, Vol. 29, No.1, 35-57.

Sugiyono. (2009). Metodologi Penelitian Kuantitatif Kualitatif dan $R \& D$. Alfabeta (Cetakan ke). Bandung.

Suprasto, B. (2003). Peluang dan Tantangan Implementasi Anggaran Berbasis Kinerja. Buletin Studi Ekonomi, Vol. 11, 270-281.

Suryana. (2018). Pengaruh Pendapatan Asli Daerah (PAD), Dana Alokasi Umum (DAU ), Dana Alokasi Khusus ( DAK ) Terhadap Belanja Modal The Influence of Local Revenue ( PAD ), General Allocation Fund ( DAU ), Special Allocation Fund ( DAK ) on Capital Expenditure Abstrak. Jurnal Ilmu Manajemen \& Bisnis, 9(2), 67-74.

Susantih, H \& Saftiana, Y. (2009). Perbandingan Indikator Kinerja Keuangan Pemerintah Provinsi se-Sumatera Bagian Selatan. Prosiding SNA 15.

Wahyudi, Muhamad and Wulandari, E. (2017). Era Otonomi Daerah (Studi Kasus Pemerintah Daerah Kota Magelang). Jurnal RAK Vol. 2 No.3 (Riset Akuntansi Keuangan), 2(3).

Wandira, A. G. (2013). Pendapatan Asli Daerah Dana Alokasi Umum. Accounting Analysis Journal, 2(33). 